БIOXIMIЯ

BIOCHEMISTRY

https://doi.org/10.15407/dopovidi2021.04.103

УДК 577.112.6:576.36.017.6:611.018.22:57.086.13

О.К. Гулевський, https://orcid.org/0000-0002-4676-3375

Н.М. Моiсєєва, https://orcid.org/0000-0002-9845-2317

О.Л. Горіна, https://orcid.org/0000-0003-4075-650X

Інститут проблем кріобіології і кріомедицини НАН України, Харків

E-mail: ogorina2603@gmail.com

\title{
Нейропептид кіоторфін запобігає розвитку апоптозу фібробластів лініі L929 в умовах холодового стресу
}

Представлено академіком НАН України А.М. Гольщевим

Досліджено протиапоптотичну дію нейропептиду кіоторфін на моделі холодового стресу фібробластів лінії L929. Вплив дипептиду на клітини аналізували за морфологічними показниками, за допомогою цитофлуориметрї з одночасним фарбуванням аппехіп V/7-AAD та дослідженням виходу цитохрому с до иитоплазми клітин. У вибраних умовах холодового стресу відмічено вірогідне збільшення кількості клітин з морфологічними ознаками апоптозу за даними світлової мікроскопї̈, порушення асиметрії мембрани та зареєстровано появу в цитоплазмі клітин цитохрому с. Доведено, що додавання кіоторфіну в концентраиії 100 мкг/л до середовища культивування за 15 хв до моделювання холодового стресу сприяло вірогідному зменшенню кількості клітин з ознаками апоптозу. Кількість аппехіп $V+/ 7-A A D^{-}$-клітин після попередньої інкубації фібробластів з дипептидом знижувалась до 19,1 \pm 0,5\% порівняно зі зразками після холодового стресу $(55,3 \pm 2,1 \%)$, а кількість клітин, в цитоплазмі яких зареєстровано цитохром с, зменшувалася в 3,65 раза. На підставі результатів досліджень висловлено припущення, що попередня інкубація з регуляторним нейропептидом кіоторфін у конщентрації 100 мкг/л ефективно запобігає апоптозу у фібробласmax L929 в умовах холодового стресу.

Ключові слова: холодовий стрес, апоптоз, кіоторфін, фібробласти L929.

Раніше нами було показано, що холодовий стрес, який являє собою циклічний процес перебування біооб'єктів у гіпотермічних умовах з подальшим відігріванням до нормотермії, призводить до появи апоптозу в клітинах in vivo та in vitro [1]. 3 літературних джерел відомо, що синтетичний аналог ендогенного лей-енкефаліну препарат “Даларгін” у гіпотермічних умовах виявляє захисну дію щодо клітин і тканин від патологічних змін [2]. Як механізми протекторної дії гексапептиду називають антиокиснювальний ефект і його здатність зв’язуватися з опіоїдними рецепторами клітинних мембран, що призводить до їх модифікації та нормалізації роботи іонтранспортних систем [3].

Ц и т у в анн я: Гулевський О.К., Моісєєва Н.М., Горіна О.Л. Нейропептид кіоторфін запобігає розвитку апоптозу фібробластів лінії L929 в умовах холодового стресу. Допов. Наи. акад. наук Укр. 2021. № 4. C. 103-109. https://doi.org/10.15407/dopovidi2021.04.103 
Гіпотетично таку властивість можуть мати природні нейропептиди з мозку тварин-гібернаторів, зокрема кіоторфін (Tyr-Arg), який має опіатоподібну активність. Найпершим фізіологічним ефектом цього дипептиду описано рилізинг мет-енкефаліну з нервових закінчень, що може обумовлювати прояв анальгезії після його введення [4]. Пізніше була показана роль кіоторфіну в механізмах природних гіпометаболічних станів на тваринах-гібернаторах, а також на незимосплячих залежно від температури та стану тварин [5]. Водночас на сьогодні нічого не відомо про протекторний вплив цього нейропептиду стосовно збереження клітин за умов холодового стресу. Зважаючи на вищесказане, ми ставили за мету дослідження протиапоптотичної дії нейропептиду кіоторфін на моделі холодового стресу фібробластів лінії L929.

Матеріали та методи. У дослідженні використовували культуру фібробластів L929, яку підтримували на живильному середовищі DMEM/F12 (“Biowest”, Франція), доповненому 10 \% фетальної телячої сироватки (“Biowest”, Франція), 200 Од/мл бензилпеніциліну (“Arterium”, Україна) та 200 мкг/мл стрептоміцину (“Arterium”, Україна), у зволоженому інкубаторі з $5 \% \mathrm{CO}_{2}$ при $37^{\circ} \mathrm{C}$.

Перед моделюванням холодового стресу клітини переносили у 24-лункові планшети (“SPL Life Sciences”, Корея) у концентрації 0,5 · $10^{6}$ клітин/мл і культивували протягом 7 діб у стандартних умовах. Після утворення моношару на 7-му добу планшети переносили в льодову баню і витримували при $0-2{ }^{\circ} \mathrm{C} 20$ хв, далі культуру повертали в умови нормотермії $\left(5 \% \mathrm{CO}_{2}, 37^{\circ} \mathrm{C}\right)$ на 60 хв. Паралельно вели культуру, яку не піддавали дії холоду (контроль).

Для дослідження дії нейропептиду кіоторфін (ТОВ “Пептидные Технологии”, РФ) на фібробласти, піддані холодовому стресу, препарат додавали у концентрації 100 мкг/л до середовища культивування за 15 хв до моделювання холодового стресу. У контрольні зразки та зразки без препарату додавали еквівалентний об’єм фізіологічного розчину.

Морфологію клітин досліджували методом світлової мікроскопії (“PZO-Warszava”, Польща) під імерсією (ок. 8, об. 100) після забарвлення гематоксиліном та еозином. Після холодового стресу моношар трипсинізували розчином трипсину (0,25 \% (“Sigma”, США)) у розчині версену ("РАА”, США), витримували 5 хв і відмивали від ферментного розчину середовищем DMEM/F12. Далі клітини промивали фосфатно-сольовим буферним розчином (PBS) і фіксували в метанолі, додавали 1 \% розчин гематоксиліну (Sigma-Aldrich, США) 3 подальшим промиванням PBS та забарвленням 1 \% розчином еозину (Sigma-Aldrich, США). Наявність апоптотичних змін у клітинах аналізували за такими ознаками клітин: пікноз клітин, фрагментація ядра та блебінг. Усього підраховували по 200 клітин у зразку. Кількість клітин з ознаками апоптозу виражали у відсотках до загальної кількості підрахованих клітин.

Подвійне забарвлення апnехіп V ma 7-AAD. Після холодового стресу моношар трипсинізували як описано вище. Далі відмивали 1х розчином PBS та після центрифугування інкубували в 100 мкл буфера для зв'язування annexin V (0,1 M Hepes/NaOH $(\mathrm{pH} 7,4)$, 1,4 M NaCl, 25 мM CaCl 2 ), що містить 5 мкл FITS-кон'югованого annexin V (BD Biosciences, США) та 5 мкл (2,5 мкг/мл) 7-AAD (BD Biosciences, США), протягом 10 хв при кімнатній температурі в темряві. Клітини аналізували з використанням протокового цитометра FACS Calibur та програмного забезпечення Cell Quest (BD Biosciences, США). За $100 \%$ приймали 10000 клітин. Одночасне забарвлення вітальним ДНК-специфічним барвником 7-AAD та annexin V, який має високу афінність до фосфатидилсерину, дає змогу ди- 
ференціювати клітини на стадії апоптозу (annexin $\mathrm{V}^{+} / 7-\mathrm{AAD}^{-}$) від вже загиблих (annexin $\mathrm{V}^{+} / 7-\mathrm{AAD}^{+}$, некроз) [6].

Дослідження виходу цитохрому с до цитоплазми. Клітинну культуру переводили в 96-лунковий планшет у концентрації 0,5 · $10^{6}$ клітин/мл і культивували протягом 48 год. Після утворення моношару відтворювали холодовий стрес як описано вище. Після 60 хв інкубації в умовах нормотермії видаляли культуральне середовище з лунок, промивали $1 \mathrm{x}$ PBS і фіксували клітини в буфері BD Cytofix (BD Biosciences, США) протягом 10 хв. Пермеабілізацію клітин та подальші етапи промивання проводили за допомогою буфера $1 \mathrm{x}$ Perm/Wash (BD Biosciences, CША) за інструкцією виробника. Після цього в кожну лунку додавали по 50 мкл моноклональних антитіл 6Н2.В4 до цитохрому с, кон'югованих з Aleха Fluor® 488 (BD Biosciences, CША), та інкубували в темряві. Антитіла видаляли триразовим промиванням буфером 1x Perm/Wash. Після заключного промивання забарвлювали ядра клітин додаванням 2 мкг/мл розчину Hoechst 33342 (Sigma-Aldrich, США) за рекомендованою виробником процедурою аналізу. Інтенсивність флуоресценції реєстрували за допомогою конфокального лазерного сканувального мікроскопа (“Carl Zeiss”, Німеччина). Для візуалізації, підрахунку кількості забарвлених клітин використовували програми LSM 510 та LSM Image Examiner. За 100 \% приймали 200 клітин.

Статистичну обробку отриманих результатів проводили з використанням програми Statgraphics plus for Windows 2.1 (“Manugistics Inc.”, США) за непараметричним критерієм Манна-Уітні. Експериментальні дані наведені як середнє арифметичне \pm середнє квадратичне відхилення. Статистично значущими вважали відмінності при $p<0,05$.

Результати досліджень. Для виявлення та дослідження клітин, що знаходяться у стані апоптозу, розроблено безліч різноманітних методів та їх модифікацій. Ці методи базуються на реєстрації подій, пов’язаних зі зменшенням розмірів та збільшенням щільності клітин, змінами складу зовнішньої мембрани, фрагментацією ядерної ДНК, змінами вмісту молекулярних маркерів апоптозу [7, 8].

Морфологічна картина апоптозу включає зменшення об'єму клітини, конденсацію й фрагментацію ядра та блебінг плазматичної мембрани, що виявляється методом світлової мікроскопії препаратів, забарвлених гематоксиліном та еозином [8]. Тому на першому етапі досліджень антиапоптотичну дію синтетичного нейропептиду кіоторфін оцінювали на моделі холодового стресу фібробластів лінії L929 за морфологічними показниками апоптозу. Як видно з рис. 1, після холодового стресу кількість клітин з апоптотичними ознаками вірогідно збільшувалася в 5,3 раза щодо контролю. У досліді з попередньою інкубацією фібробластів з нейропептидом перед холодовим стресом кількість апоптотичних клітин зменшувалася $(19,3 \pm 1,4 \%, p<0,05)$ відносно значень для зразків, підданих холодовому стресу, але вірогідно $(p<0,05)$ перевищувала контрольні показники.

Одними з ранніх показників запуску апоптозу в еукаріотичних клітинах є біохімічні зміни у фосфоліпідному бішарі плазматичної мембрани, що виявляється в переміщенні фосфатидилсерину на iํ зовнішню сторону. Це призводить до втрати асиметрії плазматичної мембрани [7]. Для ідентифікації цього процесу загальноприйнятим є використання рекомбінантного білка annexin $\mathrm{V}$, який має високу афінність до фосфатидилсерину, разом 3 катіонним барвником 7-AAD, здатним проникати всередину клітини тільки у разі порушення цілісності цитоплазматичної мембрани [6]. У таблиці наведені дані щодо кількості 


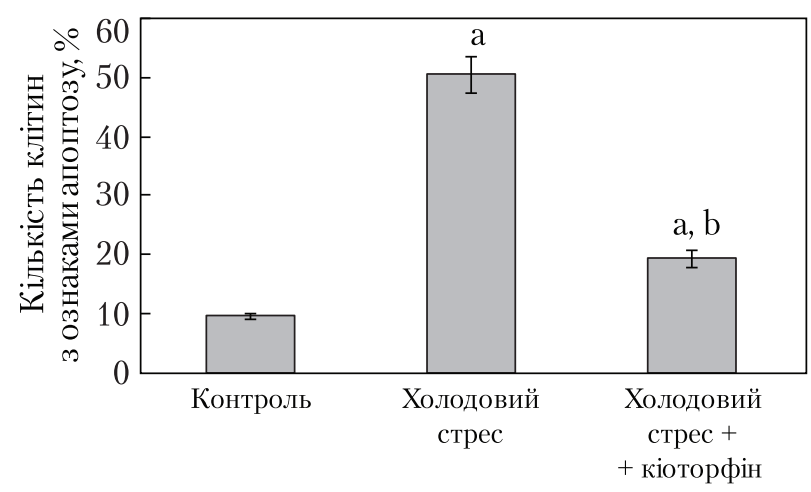

Puc. 1. Кількість апоптотичних фібробластів L929, підданих холодовому стресу та попередній інкубації з кіоторфіном (100 мкг/л). За 100 \% приймали 200 клітин. а - відмінності вірогідні $(p<0,05)$ порівняно з контролем; b - відмінності вірогідні $(p<0,05)$ порівняно зі значеннями для зразків після холодового стресу; $n=5$

annexin $\mathrm{V}^{+} / 7-\mathrm{AAD}^{-}$та annexin $\mathrm{V}^{+} / 7$ - $\mathrm{AAD}^{+}$-клітин у суспензії фібробластів після холодового стресу. Результати досліджень свідчать про те, що після холодового стресу (20 хв при $0{ }^{\circ} \mathrm{C}$ 3 подальшим поверненням в умови нормотермії на 60 хв при $37{ }^{\circ} \mathrm{C}$ ) зареєстровано підвищення кількості клітин з порушенням асиметрії мембрани порівняно з контролем (інтактними клітинами). Встановлено, що в контрольній групі відносна кількість annexin $\mathrm{V}^{+} / 7$ $\mathrm{AAD}^{-}$-клітин (клітини в стадії апоптозу) становила 15,1 \pm 1,1 \% всієї популяції, а після холодового стресу $-55,3 \pm 2,1$ \%. Завдяки інкубації клітин із синтетичним нейропептидом кіоторфін у концентрації 100 мкг/л перед холодовим стресом цей показник вірогідно знизився до 19,1 \pm 0,5 \% відносно значень зразків, які піддавалися тільки дії холодового стресу.

За результатами аналізу кількості клітин з ознаками некрозу (annexin $\mathrm{V}^{+} / 7-\mathrm{AAD}^{+}$клітини) встановлено, що в нормі їх кількість не перевищувала 7,2 \pm 0,6 \%, проте за умов холодового стресу збільшувалася до 18,1 \pm 1,4 \%. Після додавання кіоторфіну кількість annexin $\mathrm{V}^{+} / 7-\mathrm{AAD}^{+}$-клітин достовірно зменшувалася і становила 10,3 \pm 0,2\%.

Як відомо, апоптоз, спричинений зниженням температури нижче фізіологічної норми (не екстремальні низькі температури), розвивається за мітохондріальним шляхом запуску цього процесу. Гіпотермія призводить до змін біологічної функції мітохондрій, при цьому спостерігається зниження трансмембранного потенціалу, порушення проникності мітохондріальних мембран та вихід цитохрому с і ряду інших білків у цитозоль [9]. Отже, поява в цитоплазмі клітин цитохрому $c$ є маркером апоптотичного процесу. У вибраних нами умовах експерименту холодовий стрес призводить до збільшення кількості клітин, у цитоплаз-

Вплив нейропептиду кіоторфін на кількість апоптотичних (annexin $\mathrm{V}^{+} / 7-\mathrm{AAD}^{-}$) та некротичних (annexin $\mathrm{V}^{+} / 7-\mathrm{AAD}^{+}$) фібробластів L929 у контролі і після холодового стресу, \%, $n=5$

\begin{tabular}{|c|c|c|c|}
\hline Показник & Контроль & Холодовий стрес & $\begin{array}{c}\text { Холодовий стрес }+ \\
\text { + кіоторфін }\end{array}$ \\
\hline Annexin $\mathrm{V}^{+} / 7-\mathrm{AAD}^{-}$ & $15,1 \pm 1,1$ & $55,3 \pm 2,1^{\mathrm{a}}$ & $19,1 \pm 0,5^{\mathrm{c}}$ \\
Annexin $\mathrm{V}^{+} / 7-\mathrm{AAD}^{+}$ & $7,2 \pm 0,6$ & $18,1 \pm 1,4^{\mathrm{b}}$ & $10,3 \pm 0,2^{\mathrm{d}}$ \\
\hline
\end{tabular}

${ }^{a}$ Відмінності вірогідні $(p<0,05)$ порівняно з кількістю annexin $\mathrm{V}^{+} / 7$-AAD ${ }^{-}$-клітин у контролі.

${ }^{\mathrm{b}}$ Відмінності вірогідні $(p<0,05)$ порівняно 3 кількістю annexin $\mathrm{V}^{+} / 7$-AAD ${ }^{+}$-клітин у контролі.

${ }^{\mathrm{c}}$ Відмінності вірогідні $(p<0,05)$ порівняно з кількістю annexin $\mathrm{V}^{+} / 7-\mathrm{AAD}^{-}$-клітин у зразках після холодового стресу.

${ }^{\mathrm{d}}$ Відмінності вірогідні $(p<0,05)$ порівняно з кількістю annexin $\mathrm{V}^{+} 7 / \mathrm{AAD}^{+}$-клітин у зразках після холодового стресу. 
Puc. 2. Вплив попередньої інкубації фібробластів L929 з нейропептидом кіоторфін (100 мкг/л) на кількість фібробластів, у цитоплазмі яких виявлено цитохром $c$, після холодового стресу. За $100 \%$ приймали 200 клітин. а - відмінності вірогідні $(p<0,05)$ порівняно з контролем; b - відмінності вірогідні $(p<0,05)$ порівняно зі значеннями для зразків після холодового стресу; $n=5$



мі яких виявлено цитохром $c$, до рівня 26,3 \pm 2,1 \% (рис. 2). Попередня інкубація з кіоторфіном у концентрації 100 мкг/л сприяла вірогідному $(p<0,05)$ зменшенню цього показника після холодового стресу до 7,2 $\pm 1,2 \%$, рівня контрольних значень.

Обговорюючи механізм протекторної дії кіоторфіну на підставі наявних експериментальних результатів, можна допустити, що, найімовірніше, він носить рецепторний характер, хоча конкретні дані за цим питанням нам невідомі. Водночас за результатами деяких робіт, дипептид регулює транспорт $\mathrm{Ca}^{2+}$ як через плазматичну, так і через мітохондріальну мембрани. Зокрема, кіоторфін, який був виділений з мозку ховраха, що гібернує, в ізольованих препаратах серця (волокна передсердя та окремі клітини шлуночка) жаби блокував транспорт $\mathrm{Ca}^{2+}$ через канали, а в ізольованих кардіоміоцитах щурів та ховрахів - збільшував його. Це вказує на видоспецифічність дії кіоторфіну відносно іонного транспорту в серцевих клітинах [10]. В експериментах з використанням клітинних культур показано, що кіоторфін окрім стимуляції $\mathrm{Ca}^{2+}$-сигналізації впливає на проліферацію залежно від концентрації пептиду в середовищі та умов культивування [11]. Негативна дія кіоторфіну на індуковані норадреналіном ріст преадипоцитів і синтез ДНК у клітинах, що культивуються, а також пригнічення $\mathrm{Ca}^{2+}$-відповіді свіжовиділених клітин на норадреналін відмічалися тільки у вузькому діапазоні концентрацій дипептиду. Крім того, дані зазначених робіт підтверджують наявність рецепторів до кіоторфіну й у периферичних тканинах, де пептид може виконувати функцію регулювання мітогенної активності. Ряд дослідників встановили, що рівень кіоторфіну в спинномозковій рідині знижується у пацієнтів із захворюванням Альцгеймера в стані хронічного болю, а це може служити біомаркером для оцінки болю незалежно від рівня когнітивних порушень хворого [12]. Проте досі не встановлено точний механізм дії дипептиду, а ймовірний рецептор ще не ідентифікований [13].

Не виключено, що як і даларгін (синтетичний аналог ендогенного лей-енкефаліну) [3], кіоторфін може впливати на утворення активних форм кисню в клітинах фібробластів. Порівнюючи ефективність антиапоптотичної дії даларгіну [1] та кіоторфіну, можна побачити, що вона дуже близька і це опосередковано вказує на подібний механізм дії, який, імовірно, пов’язаний з регуляцією транспорту іонів кальцію та його вивільненням з клітинних депо.

Узагальнюючи вищесказане, можна зробити висновок, що попередня інкубація з кіоторфіном у концентрації 100 мкг/л ефективно пригнічує апоптоз у фібробластах L929 в умовах холодового стресу. З’ясування питань характеру рецепції та механізмів захисної дії нейропептидів в умовах холодового стресу залишається відкритим. 


\section{ЦИТОВАНА ЛІТЕРАТУРА}

1. Гулевський О.К., Моісєєва Н.М., Горіна О.Л. Антиапоптотична дія нейропептиду лей-енкефаліну щодо лейкоцитів донорської крові, підданих холодовому стресу. Допов. Нащ. акад. наук Укр. 2019. № 4. C. 94-100. https://doi.org/10.15407/dopovidi2019.04.094

2. Лишманов Ю.Б., Маслов Л.Н., Нарыжная Н.В., Пей Ж., Колар Ф., Жанг И., Портниченко А.Г., Ванг Х. Эндогенная опиоидная система как звено срочной и долговременной адаптации организма к экстремальным воздействиям. Перспективы клинического применения опиоидных пептидов. Вестн. Рос. академии мед. наук. 2012. 67, № 6. C. 73-82. https://doi.org/10.15690/vramn.v67i6.287

3. Таджибова Л.Т., Астаева М.Д., Исмаилова Ж.Г., Даудова Т.Н., Кличханов Н.К. Влияние даларгина на свободнорадикальные процессы в крови крыс при умеренной гипотермии. Бюлл. эксп. биологии и медищины. 2010. 150, № 9. С. 271-274. https://doi.org/10.1007/s10517-011-1128-z

4. Shiomi H., Kuraishi Y., Ueda H., Harada Y., Amano H., Takagi H. Mechanism of kyotorphin-induced release of Met-enkephalin from guinea pig striatum and spinal cord. Brain. Res. 1981. 221, № 1. P. 161-169. https:// doi.org/10.1016/0006-8993(81)91070-2

5. Игнатьев Д.А., Сухова Г.С., Ляшков А.Е. Температурные и кардиотропные эффекты пептидов киоторфина и неокиоторфина в опытах на зимоспящих и незимоспящих животных. Успехи физиол. наук. 2009. 40, № 3. C. $68-88$.

6. van Engeland M., Nieland L.J., Ramaekers F.C., Schutte B., Reutelingsperger C.P. Annexin V-affinity assay: a review on an apoptosis detection system based on phosphatidylserine exposure. Cytometry. 1998. 31, № 1. P. 1-9. https://doi.org/10.1002/(sici)1097-0320(19980101)31:1<1::aid-cyto1>3.0.co;2-r

7. Neves A.A., Brindle K.M. Imaging cell death. J. Nucl. Med. 2014. 55, № 1. P. 1-4. https://doi.org/10.2967/ jnumed.112.114264

8. Elmore S. Apoptosis: a review of programmed cell death. Toxicol. Pathol. 2007. 35, № 4. P. 495-516. https:// doi.org/10.1080/01926230701320337

9. Kong X., Liu H., He X., Sun Y., Ge W. Unraveling the mystery of cold stress-induced myocardial injury. Front. Physiol. 2020. № 11. 580811. https://doi.org/10.3389/fphys.2020.580811

10. Kokoz Y.M., Zenchenko K.I., Alekseev A.E., Korystova A.F., Lankina D.A., Ziganshin R.H., Mikhaleva I.I., Ivanov V.T. The effect of some peptides from the hibernating brain on $\mathrm{Ca}^{2+}$ current in cardiac cells and on the activity of septal neurons. FEBS Lett. 1997. 411, № 1. P. 71-76. https://doi.org/10.1016/s00145793(97)00607-8

11. Бронников Г.Е., Колаев С.Г., Долгачева Л.П., Крамарова Л.И. Киоторфин подавляет пролиферацию и $\mathrm{Ca}^{2+}$-сигнализацию бурых преадипоцитов. Бюлл. эксп. биологии и медищины. 2006. 141, № 2. С. 184-186.

12. Santos S.M., Garcia-Nimo L., Sá Santos S., Tavares I., Cocho J.A., Castanho M.A. Neuropeptide kyotorphin (Tyrosyl-Arginine) has decreased levels in the cerebro-spinal fluid of Alzheimer's disease patients: potential diagnostic and pharmacological implications. Front. Aging. Neurosci.2013. 5. Art. 68. https://doi.org/10.3389/ fnagi.2013.00068

13. Perazzo J., Castanho M.A., Sá Santos S. Pharmacological potential of the endogenous dipeptide kyotorphin and selected derivatives. Front. Pharmacol. 2017. 7. Art. 530. https://doi.org/10.3389/fphar.2016.00530

Надійшло до редакції 27.04.2021

\section{REFERENCES}

1. Gulevsky, A. K., Moiseyeva, N. N. \& Gorina, O. L. (2019). Antiapoptotic effect of leu-enkephalin neuropeptide on donor blood leukocytes under cold stress. Dopov. Nac. akad. nauk Ukr., No. 4, pp. 94-100 (in Ukrainian). https://doi.org/10.15407/dopovidi2019.04.094

2. Lishmanov, Y. B., Maslov, L. N., Naryzhnaya, N. Y., Pej, Z. H., Kolar, F., Zhang, I., Portnichenko, A. G. \& Vang, H. (2012). Endogenous opioid system as a mediator of acute and long-term adaptation to stress. Vestnik Rossijskoj akademii medicinskih nauk, 67, No. 6, pp. 73-82 (in Russian). https://doi.org/10.15690/vramn. v67i6.287

3. Tadzhibova, L. T., Astaeva, M. D., Ismailova, J. G., Daudova, T. N. \& Klichkhanov, N. K. (2011). Effects of dalargin on free radical processes in the blood of rats exposed to moderate hypothermia. Bull. Exp. Biol. Med., 150, No. 3, pp. 304-306. https://doi.org/10.1007/s10517-011-1128-z 
4. Shiomi, H., Kuraishi, Y., Ueda, H., Harada, Y., Amano, H. \& Takagi, H. (1981). Mechanism of kyotorphininduced release of Met-enkephalin from guinea pig striatum and spinal cord. Brain. Res., 221, No. 1, pp. 161169. https://doi.org/10.1016/0006-8993(81)91070-2

5. Ignatiev, D. A., Sukhova, G. S. \& Liashkov, A. E. (2009). Temperature and cardiotropic effects of kiotorphyn and neokiotorphyn in hibernating and nonhibernating animals. Uspekhi Fiziologicheskih Nauk, 40, No. 3, pp. 68-88 (in Russian).

6. van Engeland, M., Nieland, L. J., Ramaekers, F. C., Schutte B. \& Reutelingsperger, C. P. (1998). Annexin $\mathrm{V}$-affinity assay: a review on an apoptosis detection system based on phosphatidylserine exposure. Cytometry, 31, No. 1, pp. 1-9. https://doi.org/10.1002/(sici)1097-0320(19980101)31:1<1::aid-cyto1>3.0.co;2-r

7. Neves, A. A. \& Brindle, K. M. (2014). Imaging cell death. J. Nucl. Med., 55, No. 1, pp. 1-4. https://doi. org/10.2967/jnumed.112.114264

8. Elmore, S. (2007). Apoptosis: a review of programmed cell death. Toxicol. Pathol., 35, No. 4, pp. 495-516. https://doi.org/10.1080/01926230701320337

9. Kong, X., Liu, H., He, X., Sun, Y. \& Ge, W. (2020). Unraveling the mystery of cold stress-induced myocardial injury. Front. Physiol., No. 11, 580811. https://doi.org/10.3389/fphys.2020.580811

10. Kokoz, Y. M., Zenchenko, K. I., Alekseev, A. E., Korystova, A. F., Lankina, D. A., Ziganshin, R. H., Mikhaleva, I. I. \& Ivanov, V. T. (1997). The effect of some peptides from the hibernating brain on Ca2+ current in cardiac cells and on the activity of septal neurons. FEBS Lett., 411, No. 1, pp. 71-76. https://doi.org/10.1016/s00145793(97)00607-8

11. Bronnikov, G. E., Kolaeva, S. G., Dolgacheva, L. P. \& Kramarova, L. I. (2006). Kyotorphin suppresses proliferation and Ca2+ signaling in brown preadipocytes. Bull. Exp. Biol. Med., 141, pp. 223-225. https://doi. org/10.1007/s10517-006-0133-0

12. Santos, S. M., Garcia-Nimo, L., Sá Santos, S., Tavares, I., Cocho, J. A. \& Castanho, M. A. (2013). Neuropeptide kyotorphin (Tyrosyl-Arginine) has decreased levels in the cerebro-spinal fluid of Alzheimer's disease patients: potential diagnostic and pharmacological implications. Front. Aging. Neurosci., 5, art. 68. https://doi. org/10.3389/fnagi.2013.00068

13. Perazzo, J., Castanho, M. A. \& Sá Santos, S. (2017). Pharmacological potential of the endogenous dipeptide kyotorphin and selected derivatives. Front. Pharmacol., 7, art. 530. https://doi.org/10.3389/fphar.2016.00530

Received 27.04.2021

O.K. Gulevskyy, https://orcid.org/0000-0002-4676-3375

N.M. Moisieieva, https://orcid.org/0000-0002-9845-2317

O.L. Gorina, https://orcid.org/0000-0003-4075-650X

Institute for Problems of Cryobiology and Cryomedicine of the NAS of Ukraine, Kharkiv

E-mail: ogorina2603@gmail.com

\section{NEUROPEPTIDE KYOTORPHIN PREVENTS THE DEVELOPMENT OF APOPTOSIS OF FIBROBLASTS L929 UNDER COLD STRESS}

We were study the antiapoptotic effect of the neuropeptide kyotorphin in a model of cold stress fibroblasts L929. The effect of dipeptide on cells was analyzed by morphological parameters, using cytofluorimetry with simultaneous staining of annexin V/7-AAD and study of the release of cytochrome $c$ to the cytoplasm of cells. Under selected conditions of cold stress, there was a significantly increase in the number of cells with morphological features of apoptosis according to light microscopy, violation of membrane asymmetry, and the appearance of cytochrome $c$ cells in the cytoplasm was registered. It has been proved that the addition of kyotorphin at a concentration of $100 \mu \mathrm{g} / \mathrm{l}$ to the culture medium $15 \mathrm{~min}$ before the modeling of cold stress significantly reduces the number of cells features of apoptosis. The number of annexin $\mathrm{V}^{+} / 7-\mathrm{AAD}^{-}$-cells after pre-incubation of fibroblasts with dipeptide decreased to $19.1 \pm 0.5 \%$ compared to samples after cold stress $(55.3 \pm 2.1 \%)$, and the number of cells in the cytoplasm of which was registered cytochrome $c$, decreased by 3.65 times. Studies have suggested that pre-incubation with the regulatory neuropeptide kyotorphin at a concentration of $100 \mu \mathrm{g} / \mathrm{lef}$ fectively prevents apoptosis in fibroblasts L929 under cold stress.

Keywords: cold stress, apoptosis, kyotorphin, fibroblasts L929. 